\title{
Xylella fastidiosa Requires Polygalacturonase for Colonization and Pathogenicity in Vitis vinifera Grapevines
}

\author{
M.Caroline Roper, ${ }^{1}$ L. Carl Greve, ${ }^{2}$ Jeremy G. Warren, ${ }^{1}$ John M. Labavitch, ${ }^{2}$ and Bruce C. Kirkpatrick ${ }^{1}$ \\ ${ }^{1}$ Department of Plant Pathology and ${ }^{2}$ Department of Plant Sciences, University of California, Davis. Davis, CA, 95616, U.S.A. \\ Submitted 4 June 2006. Accepted 14 November 2006.
}

\begin{abstract}
Xylella fastidiosa is the causal agent of Pierce's disease of grape, an economically significant disease for the grape industry. $X$. fastidiosa systemically colonizes the xylem elements of grapevines and is able to breach the pit pore membranes separating xylem vessels by unknown mechanisms. We hypothesized that $X$. fastidiosa utilizes cell wall degrading enzymes to break down pit membranes, based on the presence of genes involved in plant cell wall degradation in the $X$. fastidiosa genome. These genes include several $\beta-1,4$ endoglucanases, several xylanases, several xylosidases, and one polygalacturonase (PG). In this study, we demonstrated that the pglA gene encodes a functional PG. A mutant in pglA lost pathogenicity and was compromised in its ability to systemically colonize Vitis vinifera grapevines. The results indicate that PG is required for $X$. fastidiosa to successfully infect grapevines and is a critical virulence factor for $X$. fastidiosa pathogenesis in grapevine.
\end{abstract}

Additional keyword: pectinase.

Pierce's disease of grapevines (PD) is an economically important disease that affects wine, table, and raisin grape production (Vitis vinifera). Xylella fastidiosa, the causal agent of $\mathrm{PD}$, is a gram-negative, xylem-limited bacterium that is transmitted by xylem-feeding insect vectors, mainly sharpshooters (family Cicadellidae) (Hopkins 1989). After introduction into the xylem, $X$. fastidiosa can establish either local or systemic infections in plants (Purcell and Saunders 1999). Once X. fastidiosa colonizes grapevine xylem tissues, symptoms can be severe, including leaf scorching, dessicated fruit ("raisining" of berries), cordon dieback, and vine death. PD-infected vines have occlusions in the xylem vessels that disrupt water flow throughout the vine (Esau 1948; Fry and Milholland 1990a and b; Goodwin et al. 1988a and b). Besides bacterial cell aggregates and tyloses, the exact origin and composition of the xylem occlusions are not known but likely are composed of host gums, bacterial exopolysaccharide, or degradation products from the host cell wall, singly or in combination.

In systemically infected plant hosts, the exact mechanism by which $X$. fastidiosa breaches the pit membrane is not known. The pit membrane is the primary cell wall that separates vessels or tracheary elements from each other. The plant primary cell wall is composed of pectin, cellulose, hemicellulose, and proteins (Keegstra et al. 1973; Carpita and Gibeaut 1993). Pectin polymers regulate the porosity of the cell-wall fabric and, most

Corresponding author: B. C. Kirkpatrick;

E-mail: bckirkpatrick@ucdavis.edu likely, pores in the intervessel pit membranes (Baron-Epel et al. 1988; Buchanan et al. 2000; Zwienecki et al. 2001). Pore sizes have been estimated to be between 5 and $20 \mathrm{~nm}$ in several plant species (Choat et al. 2003; Zimmerman et al.1983). Intact pit membranes in grapevines do not allow passage of particles larger than $5 \mathrm{~nm}$ (Labavitch et al. 2004), an exclusion limit that is much too small to allow passage of $X$. fastidiosa cells, whose diameter is 0.3 to $0.5 \mu \mathrm{m}$ (Davis et al. 1978). In order for $X$. fastidiosa to systemically colonize the vine, it is probably essential for the pit membrane barrier to be breached, because the average grapevine xylem vessel is only $10 \mathrm{~cm}$ long (Labavitch et al. 2002). The mechanism by which $X$. fastidiosa breaches this barrier is poorly understood. We hypothesize that $X$. fastidiosa utilizes polysaccharide-degrading enzymes to digest cell-wall polymers that make up the xylem pit membranes. Open reading frames (ORF) putatively encoding a polygalacturonase (PG), three endo-1,4 $\beta$-glucanases, a cellobiohydrolase, three endo- $\beta$-xylanases, and two $\beta$-xylosidases were identified in the genome of the PD strain of $X$. fastidiosa (Van Sluys et al. 2003).

PGs are important virulence factors in other plant-pathogenic bacteria, such as Ralstonia solanacearum, Agrobacterium tumefaciens, and Erwinia carotovora (Alghisi and Favron 1995; Collmer and Keen 1986; Dow et al. 1987; Huang and Allen, 2000; Koutajansky 1987; Lei et al. 1985; Prade et al. 1999; Rodriguez-Palenzuela et al. 1991; Schell et al. 1988). Based on the $65 \%$ shared amino-acid identity, the $X$. fastidiosa PG is most closely related to the endo-PG of $R$. solanacearum, another xylem-inhabiting bacterium (Salanoubat et al. 2002). In this study, we examined the single copy PG gene (PD1485; Van Sluys et al. 2003) as a potential virulence factor mediating the systemic infection of grapevines by site-directed mutagenesis and evaluated the mutant for alterations in pathogenicity and movement in grapevines.

\section{RESULTS}

Construction and confirmation of $\mathrm{pglA}$ gene replacement by marker exchange mutagenesis.

The wild-type pglA gene was disrupted using the Tn903 $<$ kan-2> cassette, and this construct was electroporated into the PD Fetzer strain of $X$. fastidiosa. Kanamycin-resistant colonies were tested for a double crossing over event by polymerase chain reaction (PCR), using the primers pgfwd and pgrev. The resulting PCR product from the pglA $X$. fastidiosa mutants was $2,916 \mathrm{bp}$, representing the wild-type pglA (1,695 bp) + Tn903<kan-2> cassette $(1,238$ bp) (Fig. 1). The insertion site of the gene replacement was identified by PCR and sequence analysis. Primers specific to the DNA flanking the pglA gene 
were used in combination with the kan-2-fp-1 and kan-2-rp-1 primers. A 1,572-bp PCR fragment was amplified with the pgchkfwd and kan-2-rp-1 primers, and a 1,542-bp fragment was amplified with the pcgchkrev and kan-2-fp-1 primers (data not shown). Sequence analysis of the resulting PCR fragments confirmed that marker exchange mutagenesis had occurred in the $p g l A$ ORF. The wild type and $p g l A^{-} X$. fastidiosa mutants exhibited similar colony morphology on solid PD3 medium (Davis et al. 1981). Growth curves of the mutant and wild-type cells were similar in PD3 liquid medium (data not shown).

\section{Pathogenicity assay.}

Grapevines (10 each) were inoculated with either wild-type $X$. fastidiosa, pglA- X. fastidiosa mutant, or $\mathrm{H}_{2} \mathrm{O}$. Plants were rated for disease severity weekly, beginning 12 weeks postinoculation. The plants inoculated with the $\mathrm{pglA}^{-} \mathrm{X}$. fastidiosa mutant never developed typical PD symptoms and were indistinguishable from the water-inoculated control vines throughout the course of the experiment (Fig. 2). Wild-type $X$. fastidios $a$-inoculated vines developed symptoms beginning 12 weeks postinoculation and exhibited a disease severity progression typical of PD-infected grapevines. Contingency table analysis showed that, beginning at 13 weeks postinoculation, the wild-type disease ratings were statistically different from those of the mutant $(P<0.01)$, with the difference increasing over time (Table 1). In the second replication, using the same number of vines, no PD symptoms developed in the vines inoculated with the $p g l A^{-} X$. fastidiosa mutants and disease progression in wild-type $X$. fastidiosa-inoculated vines was the same as in the first experiment.

\section{Movement assay.}

$X$. fastidiosa isolations were performed on petioles sampled from inoculated vines to determine the pathogen's presence or absence and to quantify populations of X. fastidiosa. X. fastidiosa isolations from the point of inoculation showed that $X$. fastidiosa was present in $80 \%$ of the vines inoculated with wild-type $X$. fastidiosa and $50 \%$ of the vines inoculated with the $p g l A^{-}$mutant, values that were not significantly different $(P>0.05)$ (Table 2). At 14 weeks postinoculation, $X$. fastidiosa was detected at $25 \mathrm{~cm}$ above the point of inoculation in $100 \%$ of the plants inoculated with wild-type $X$. fastidiosa and in only $30 \%$ of the plants inoculated with the $\mathrm{pglA}^{-} \mathrm{X}$. fastidiosa mutant. These results were statistically different $(P<$ 0.01 ), indicating that the mutant had not moved $25 \mathrm{~cm}$ upward from the point of inoculation to the extent the wild type had in 14 weeks. At 15 weeks postinoculation, $X$. fastidiosa was recovered $37 \mathrm{~cm}$ above the point of inoculation from $100 \%$ of the vines inoculated with wild-type $X$. fastidiosa and from only $45 \%$ of the vines inoculated with the $X$. fastidiosa pglAmutant $(P<0.01)$. At 20 weeks postinoculation, a second set of petioles was sampled at $25 \mathrm{~cm}$ above the point of inoculation, to determine whether the $p g l A^{-} X$. fastidiosa population had finally colonized inoculated plants. Further sampling of the wild-type inoculated plants was not possible at this time-
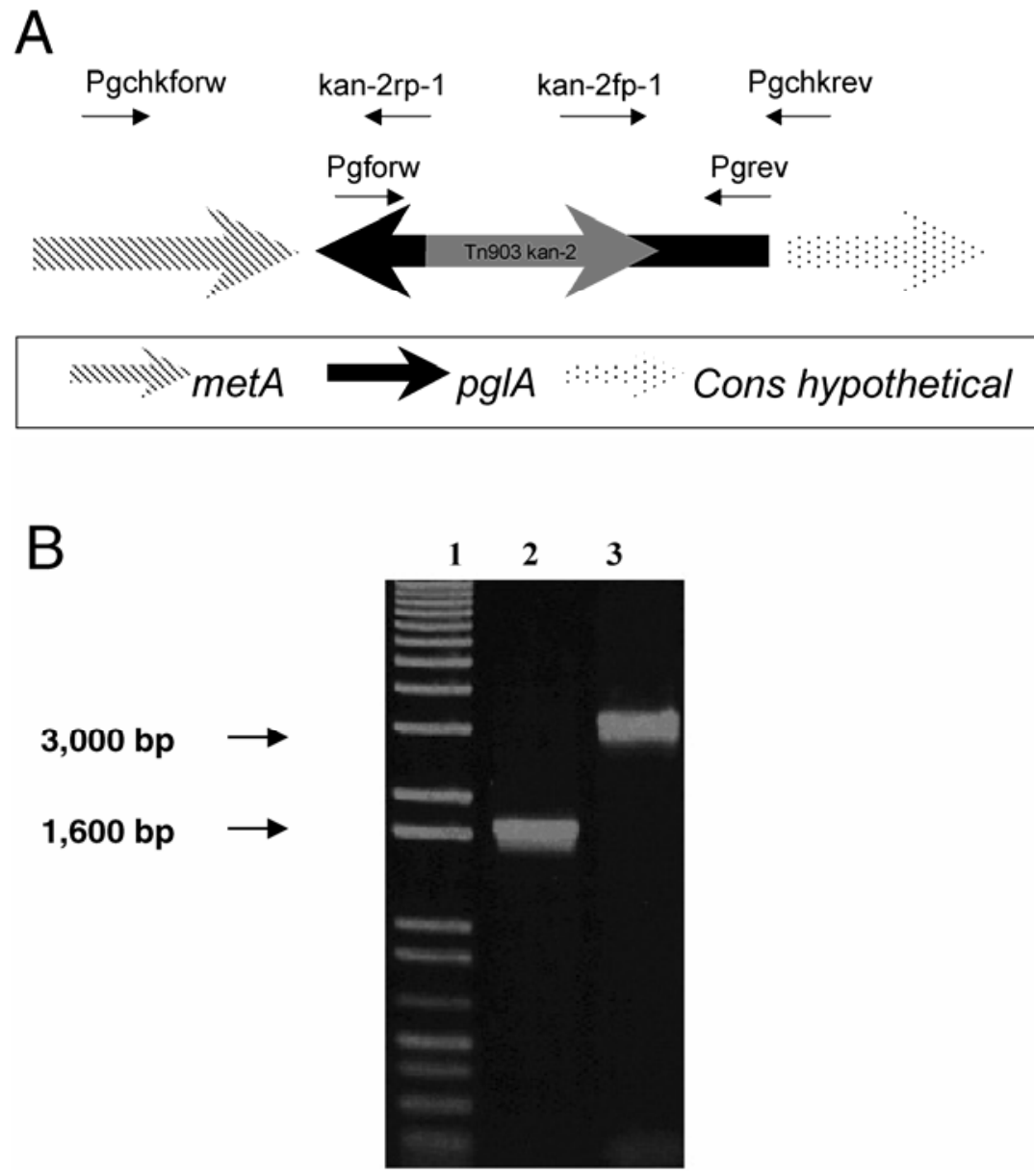

Fig. 1. Confirmation of double exchange integration of the pglA::Tn903<kan-2> cassette in the Fetzer Xylella fastidiosa chromosome by polymerase chain reaction (PCR). A, Diagram of the transcriptional orientation of the pglA and flanking genes metA and conserved hypothetical genes. B, Lane 1, 1-kb ladder; lanes 2 and 3, PCR products obtained using pgfwd and pgrev primers and DNA from the wild-type Fetzer X. fastidiosa strain or the X. fastidiosa pglA mutant, respectively. The PCR products were separated by electrophoresis in a $1.0 \%$ agarose gel. 
point, due to severe defoliation or vine death. The $\mathrm{pglA}^{-} \mathrm{X}$. fastidiosa mutant could be isolated from plants 20 weeks postinoculation, but the frequency was not statistically different from the isolations performed after 14 weeks postinoculation (Table 2).

In order to assess the genotype of the $p g l A^{-} X$. fastidiosa cells present in the grapevines inoculated with $\mathrm{pglA}^{-} X$. fastidiosa mutants, isolations were performed on PD3 medium containing kanamycin. PCR was performed on five individual pglA $A^{-}$. fastidiosa colonies, using pgchkrev and kan-2 fp-1 and pgchkfwd and kan-2 rp-1 primers (Fig. 1). The expected 1,572 bp and 1,542 PCR amplicons were obtained, thus confirming the identity of the mutants and that the mutation was stable (data not shown). No PCR fragments indicating the presence of the kanamycin gene were obtained from X. fastidiosa colonies isolated from vines inoculated with wild-type $X$. fastidiosa.

Bacterial populations were determined at the point of inoculation, 25, and $37 \mathrm{~cm}$ above the point of inoculation at 13, 14, and 15 weeks postinoculation, respectively. Based on a repeated measures analysis of variance (ANOVA) test, the populations of wild-type $X$. fastidiosa were always higher than the $p g l A^{-} X$. fastidiosa populations at each distance point measured (Table 3 ).

\section{Cloning and expression of the pglA ORF in Escherichia coli.}

The ORF PD1485 (Van Sluys et al. 2003) was cloned into the expression vector pET-29b (+) to create pMCR5. Sodium dodecyl sulfate-polyacrylamide gel electrophoresis (SDSPAGE) analysis of $E$. coli BL21 (DE3) transformed with pMCR5 confirmed that, following induction with isopropyl $\beta$ D-1-thiogalactopyranoside (IPTG), the transformed E. coli produced a recombinant protein of approximately $58.2 \mathrm{kDa}$, the expected size of the $X$. fastidiosa PglA protein. E. coli transformed with the empty vector did not accumulate any protein with the predicted size of the recombinant PG (Fig. 3).

\section{Enzymatic activity of the recombinant $X$. fastidiosa PglA.}

The crude lysates from $E$. coli transformed with pMCR5 were capable of degrading polygalacturonic acid (PGA), as indicated by the production of reducing end groups when the lysates were incubated with PGA (Fig. 4). High-performance liquid chromatography (HPLC) analysis showed that this increase in reducing potential was the result of increased concentrations of acidic oligomers, which was confirmed by coinjection of standards (obtained from the Complex Carbohydrate Research Center, Athens, GA, U.S.A) (Spiro et al. 1993) with degrees of polymerization of 10 (elution time $=25.51$ min) and 11 (elution time = $26.61 \mathrm{~min}$ ) (Fig. 5). Additionally,

Table 1. Disease severity of greenhouse-grown grapevines inoculated with wild-type Xylella fastidiosa (WT), pglA- X. fastidiosa, or $\mathrm{H}_{2} \mathrm{O}$ (control) ${ }^{\mathrm{a}}$

\begin{tabular}{llcc}
\hline Time postinoculation & \multicolumn{1}{c}{ WT } & pglA $^{-}$ & $\mathbf{H}_{\mathbf{2}} \mathbf{O}$ \\
\hline 12 weeks $_{13}$ weeks $^{\mathrm{b}}$ & $0.56 \pm 0.52$ & 0 & 0 \\
14 weeks $^{1.22 \pm 0.97}$ & 0 & 0 \\
15 weeks & $2.22 \pm 1.0$ & 0 & 0 \\
16 weeks & $2.66 \pm 1.0$ & 0 & 0 \\
17 weeks & $3.2 \pm 0.83$ & 0 & 0 \\
18 weeks & $3.4 \pm 0.76$ & 0 & 0 \\
19 weeks & $3.5 \pm 0.52$ & 0 & 0 \\
20 weeks & $4.0 \pm 0.5$ & 0 & 0 \\
21 weeks & $4.6 \pm 0.5$ & 0 & 0 \\
\hline
\end{tabular}

${ }^{a}$ Disease severity was based on a visual disease scale from 0 (no disease) to 5 (dead). Data represent the mean of the first repetition of the pathogenicity assay. The second repetition obtained similar results.

b From this timepoint on, significance detected at the $99 \%$ confidence level.

Table 2. Percentage of Chardonnay grapevines containing wild-type Xylella fastidiosa or $X$. fastidiosa pglA mutant cells in petiole tissue at various times postinoculation and distances from the point of inoculation (POI) ${ }^{\mathrm{a}}$

\begin{tabular}{|c|c|c|c|c|}
\hline \multirow[b]{3}{*}{ Genotype } & \multirow[b]{2}{*}{ POI } & \multicolumn{3}{|c|}{ Distance above POI } \\
\hline & & $25 \mathrm{~cm}$ & $37 \mathrm{~cm}$ & $25 \mathrm{~cm}$ \\
\hline & 13 weeks & 14 weeks & 15 weeks & 20 weeks \\
\hline Wild type & $80 \%$ & $100 \%$ & $100 \%$ & ND \\
\hline pglA::Tn $903<$ kan-2> & $50 \%$ & $30 \%$ & $45 \%$ & $50 \%$ \\
\hline
\end{tabular}

${ }^{\text {a }}$ Data represent the mean of two experiments inoculating 20 vines with wild-type $X$. fastidiosa or pglA $X$. fastidiosa (80 vines total); ND = not determined because vines were completely defoliated or dead.

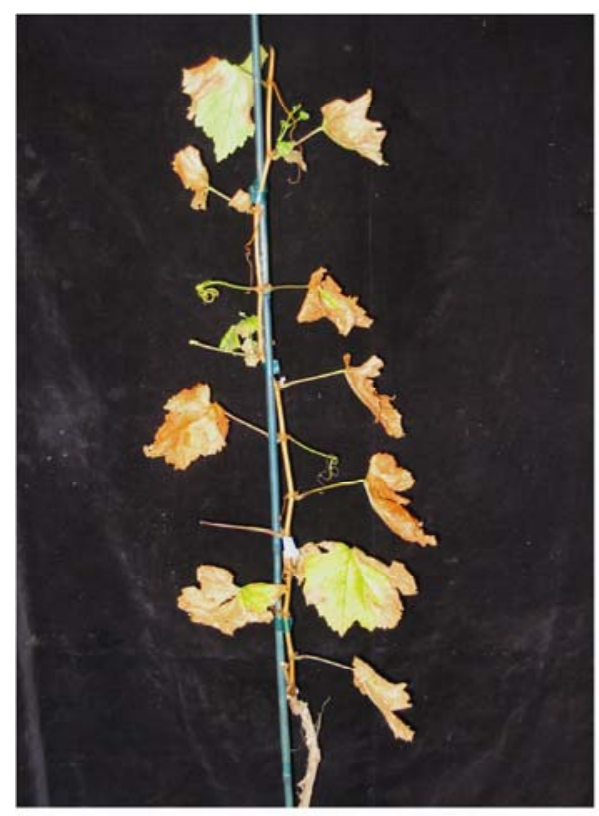

Wild Type $X f$

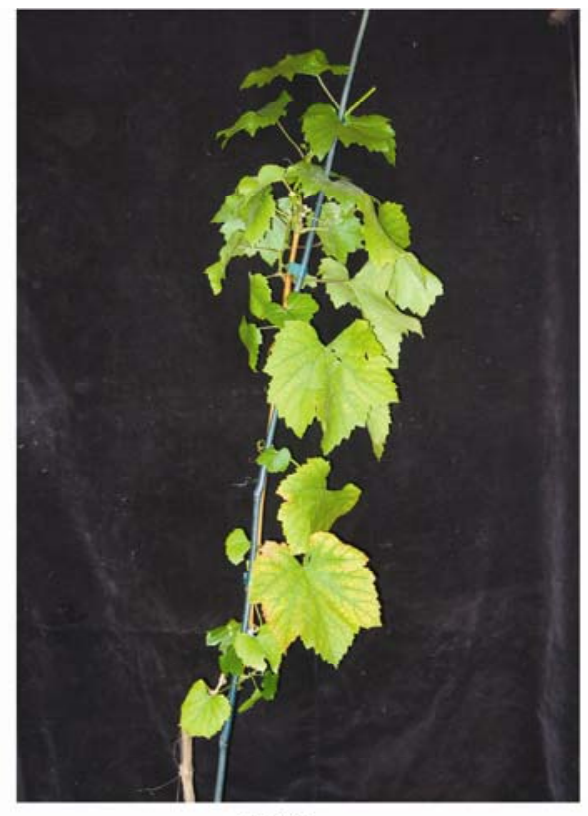

$p g I A X f$

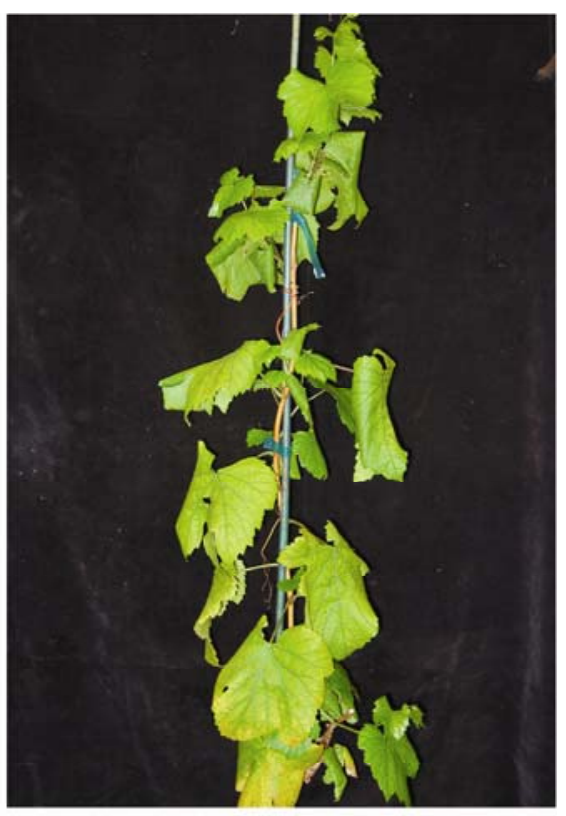

$\mathrm{H}_{2} \mathrm{O}$ Control

Fig. 2. Vitis vinifera cv. Chardonnay plants inoculated with wild-type Fetzer Xylella fastidiosa, pglA ${ }^{-}$. fastidiosa, or a water control. Plants were inoculated with $40 \mu \mathrm{l}$ of a $10^{8} \mathrm{CFU} / \mathrm{ml}$ bacterial suspension or $\mathrm{H}_{2} \mathrm{O}$. Plants shown are 18 weeks postinoculation. 
the peak eluting at $23.20 \mathrm{~min}$ tested positive for uronic acid (data not shown).

\section{DISCUSSION}

The genome sequence of the Citrus Variegated Chlorosis (CVC) and the PD Temecula strains of $X$. fastidiosa identified

Table 3. Xylella fastidiosa populations in leaf petioles collected from Chardonnay grapevines inoculated with wild-type Xylella fastidiosa (WT) and $p g l A^{-} X$. fastidiosa

\begin{tabular}{llll}
\hline Distance $^{\mathbf{a}}$ & Weeks $^{\text {b }}$ & WT $($ CFU $)$ & pglA $^{-}(\mathbf{C F U})$ \\
\hline POI & 13 & $1.7( \pm 4.3) \times 10^{5}$ & $1.3( \pm 2.4) \times 10^{5}$ \\
$25 \mathrm{~cm}$ & 14 & $1.2( \pm 3.0) \times 10^{7}$ & $2.3( \pm 4.2) \times 10^{5}$ \\
$37 \mathrm{~cm}$ & 15 & $3.5( \pm 3.7) \times 10^{7}$ & $1.5( \pm 4) \times 10^{6}$ \\
\hline
\end{tabular}

a Point of inoculation (POI) or distance above POI in centimeters.

$\mathrm{b}$ Time postinoculation.

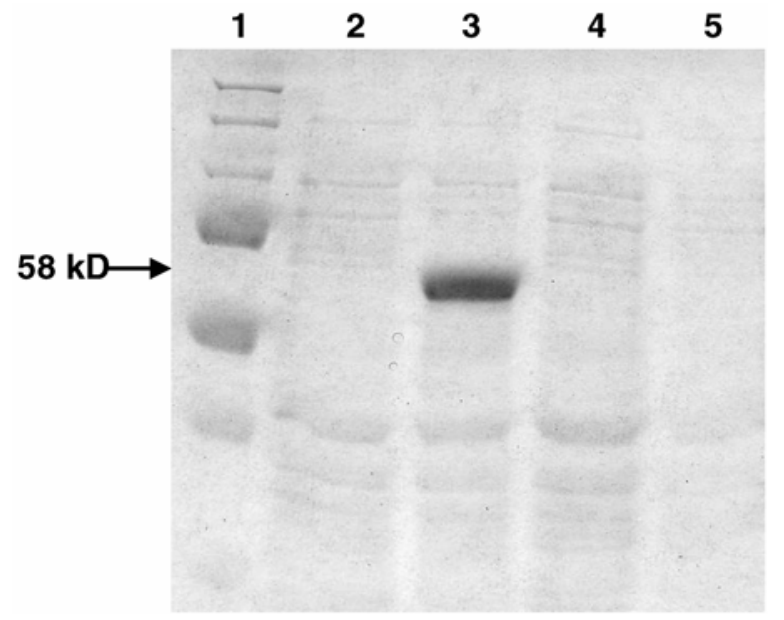

Fig. 3. Sodium dodecyl sulfate polyacrylamide gel electrophoresis gel analysis of Escherichia coli cell lysates transformed with pMCR5 or the empty pET-29b(+) vector. Lane 1, Molecular-weight ladder; lane 2, E. coli transformed with pMCR5 prior to induction with isopropyl $\beta$-D-1-thiogalactopyranoside (IPTG); lane 3, E. coli transformed with pMCR5 following induction with IPTG at $4^{\circ} \mathrm{C}$ overnight; lane $4, E$. coli transformed with pET-29b (+) prior to induction with IPTG; and lane 5, E. coli transformed with pET-29b (+) following induction with IPTG at $4^{\circ} \mathrm{C}$ overnight.

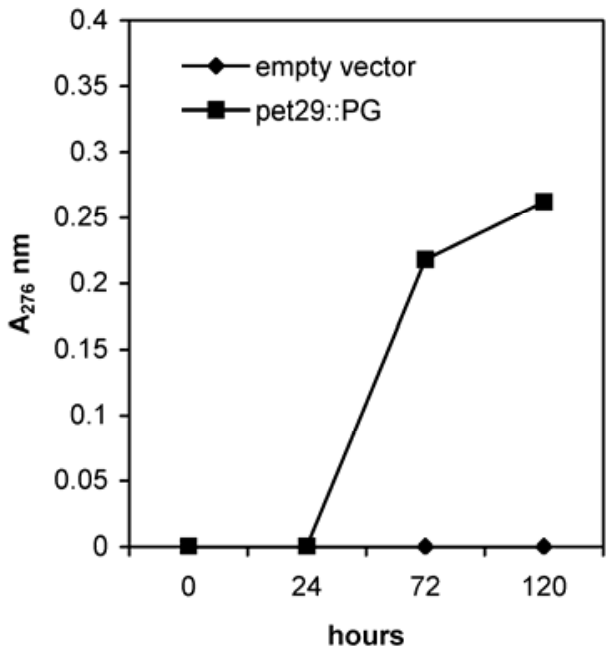

Fig. 4. Degradation of polygalacturonic acid indicated by the production of reducing ends in reaction mixtures of crude Escherichia coli lysates containing either the pMCR5 construct (pET29b::PG) or the empty pET29(b)+ vector. genes that may be involved in pathogenesis, based on their homology and known functions in other plant pathogenic bacteria (Simpson et al. 2000; Vans Sluys et al. 2003). More specifically, the analysis of the $X$. fastidiosa PD Temecula genome revealed ORF encoding putative cell wall degrading enzymes (CWDE), including a PG, three endo-1,4- $\beta$-glucanases, a cellobiohydrolase, three endoxylanases, and two $\beta$-xylosidases (Van Sluys et al. 2003). We hypothesize that $X$. fastidiosa uses these enzymes to facilitate intervessel migration, because the grapevine pit membrane pore sizes are too small to allow passive movement of the bacteria (Labavitch et al. 2002). The purpose of this study was to determine if the single copy PG gene present in the genome of a PD strain of $X$. fastidiosa encodes a functional PG protein and if this PG is important for movement or mediating pathogenicity in grapevines.

While $X$. fastidiosa contains several genes encoding potential enzymes that could possibly digest the cellulosic and hemicellulosic components of the plant cell wall, it has only one gene encoding a potential pectinase (PD1485). The X. fastidiosa $\mathrm{PG}$ is theoretically an endo-PG with high homology (65\% amino-acid identity) to the endo-PG (PglA) of $R$. solanacearum as well as high homology with the PG orthologs of $X$. campestris pv. campestris, $X$. axonopodis pv. citri, $X$. oryzae pv. oryzae, Agrobacterium vitis, and Erwinia carotovora (Van Sluys et al. 2003). Interestingly, the corresponding PG ortholog found in the $X$. fastidiosa CVC strain contains a frameshift that presumably renders the resulting protein nonfunctional. Sequencing of the PG gene from 11 strains of $X$. fastidiosa indicated that all the citrus strains examined, as well as the coffee strains that are phylogenetically similar to $X$. fastidiosa CVC, contained the same frameshift in the PG ORF (Van Sluys et al. 2003). All the other X. fastidiosa isolates including grape, almond, and mulberry do not contain the

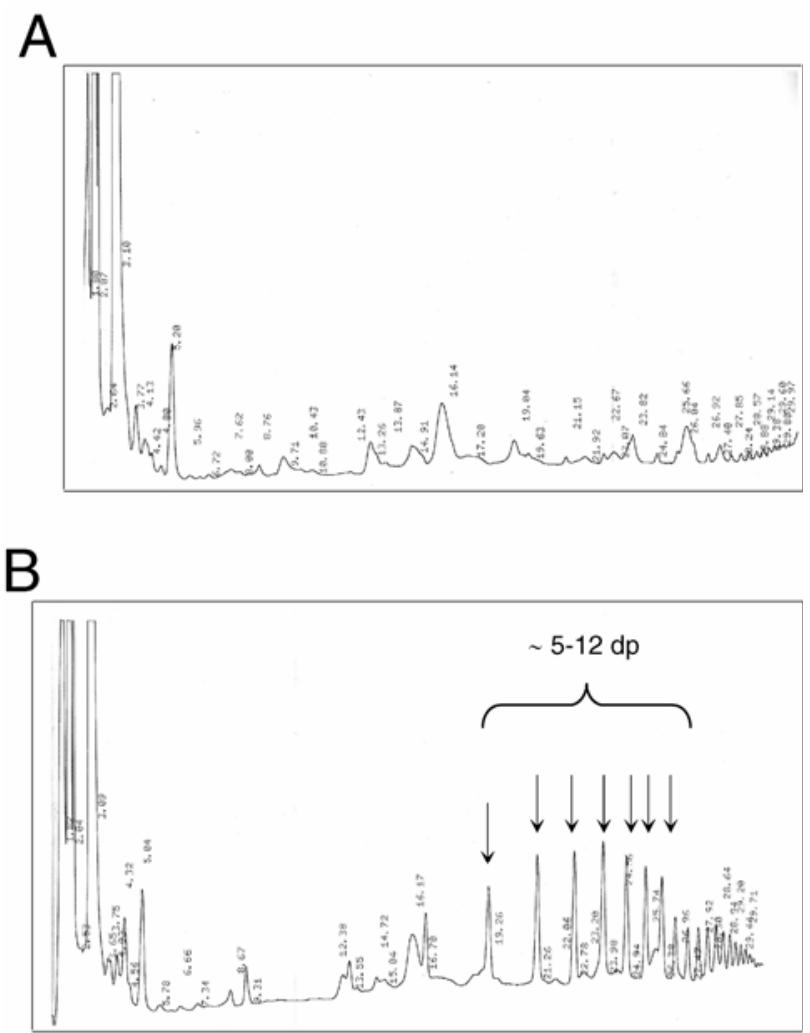

Fig. 5. High-performance liquid chromatograms of Escherichia coli lysates incubated with $0.2 \%$ polygalacturonic acid and $\mathbf{A}, E$. coli containing the empty pET29-b (+) vector or B, E. coli transformed with pMCR5. Arrows indicate oligomers with a degree of polymerization of 5 to 12 . 
frameshift. The authors proposed that the apparent lack of PG in the $X$. fastidiosa CVC strain might be responsible for the less aggressive nature of the $X$. fastidiosa CVC strain as compared with the PD X. fastidiosa strain (Van Sluys et al. 2003).

At present there is only one selectable marker that is expressed in an $X$. fastidiosa PD strain (Guilhabert et al. 2001). This limits current $X$. fastidiosa genetic studies to the use of single-gene as opposed to multiple-gene knockouts in the pathogen. We chose to investigate the role of the single-copy PG because disrupting one of the multiple glucanases or xylanases might not give a measurable effect on $X$. fastidiosa movement or virulence. For example, knocking out only one of the nine pectolytic enzymes of X. campestris pv. campestris had no effect on virulence, while a mutant deficient in the export of all of the pectolytic enzymes was nonpathogenic (Dow et al. 1987; Dow et al. 1989). In addition, it is known that pectin is a key determinant of pore size in the pit membrane (Baron-Epel et al. 1988; Zwienicki et al. 2001), and this size limitation should restrict $X$. fastidiosa from moving into adjacent vessels (either vertically or horizontally) from the vessel into which it was originally introduced by the insect vector. Therefore, the single-copy PG gene was an obvious candidate to study to better understand the involvement of host wall-degradation processes in $X$. fastidiosa pathogenesis.

The results of the movement assay indicate that the $p g l A^{-} X$. fastidiosa mutant was impeded in long-distance movement measured at 25 and $37 \mathrm{~cm}$ above the point of inoculation, as indicated by lower bacterial titers and lower frequency of $X$. fastidiosa recovery at these points (30 and $45 \%$ of the vines inoculated with the $p g l A^{-} X$. fastidiosa mutant at the 25- and $37-\mathrm{cm}$ points as opposed to $100 \%$ of vines inoculated with the wild-type $X$. fastidiosa). We conclude that the difference in movement efficiency is a result of bacteria being introduced into stem xylem pathways that are interrupted by pit membranes that cannot be digested by $p g l A^{-} X$. fastidiosa due to the absence of PG. These results are similar to those of Huang and Allen (2000), who reported that $R$. solanacearum $\mathrm{pglA}^{-} \mathrm{mu}-$ tants colonized tomato stems more slowly and at a lower frequency than wild type. We propose that $X$. fastidiosa lacking a functional PG cannot efficiently digest grapevine pit membranes and colonize xylem vessels. The average vessel length in grapevines is only $10 \mathrm{~cm}$, although longer vessels can be found at lower frequencies (Labavitch et al. 2002). Since $10 \mathrm{~cm}$ is shorter than the distances assessed in this study, wild-type $X$. fastidiosa that was recovered from points greater than $10 \mathrm{~cm}$ most likely would have traversed pit membranes during its vertical movement in the stem. Vessel to vessel pits would need to be degraded during $X$. fastidiosa horizontal movement as well (Zimmerman 1983). Newman and associates (2003) observed $X$. fastidiosa crossing multiple adjacent pit membranes simultaneously and concluded that $X$. fastidiosa must have a means of digesting this barrier rather than relying on naturally occurring tears or perforations in the pits, because it is unlikely that more that one adjacent pit would become naturally compromised. In the few instances in which the $X$. fastidiosa pglA mutant was able to move longer distances, it is probable that the bacteria were introduced into one of the few longer (30 to $50 \mathrm{~cm}$ ) grapevine xylem vessels and, therefore, would not have needed to cross pit membranes to move from the point of inoculation (Labavitch et al. 2002). Indeed, Thorne and associates (2006) have described passive movement of bacteria and flourescent beads $(1 \mu \mathrm{m})$ through open xylem grapevine conduits into leaves and this could contribute to the presence of pglA $X$. fastidiosa in leaves 25 and $37 \mathrm{~cm}$ above the point of inoculation. Their study introduced bacteria through the cut ends of grapevine stems, allowing bacteria access to all xylem conduits in the stem, therefore increasing the likelihood that bacteria would be introduced into one of the few longer vessels. In contrast, in our study, bacteria were introduced locally (pin-prick inoculation), thereby decreasing the chance that bacteria would be introduced into a long vessel. The observation that the $p g l A^{-} X$. fastidiosa was only recovered from 9 of 20 vines at $37 \mathrm{~cm}$ above the point of inoculation (Table 2) suggests that the pin-prick inoculation method does not consistently introduce $X$. fastidiosa cells into grapevine xylem elements that are longer than $10 \mathrm{~cm}$.

Compared with the $100 \%$ recovery of wild-type X. fastidiosa cells at 25 and $37 \mathrm{~cm}$ above the point of inoculation, the $p g l A^{-} X$. fastidiosa mutant was recovered at a much lower percentage (30 and $45 \%$ ) (Table 2). When allowed a longer incubation time of 20 weeks postinoculation, the $p g l A^{-} X$. fastidiosa mutant was recovered at $25 \mathrm{~cm}$ above the point of inoculation from four more vines that did not initially yield $X$. fastidiosa after 14 weeks of incubation, suggesting that xylem pit membranes can possibly be degraded by the other $X$. fastidiosa CWDE. However, the number of plants harboring the pglA $X$. fastidiosa at $25 \mathrm{~cm}$ after 20 weeks postinoculation was not statistically different from the number of plants harboring the $p g l A^{-} X$. fastidiosa mutant 14 weeks postinoculation. This observation shows that PG greatly facilitates the movement of $X$. fastidiosa in grapevines but suggests that the other $X$. fastidiosa CWDE may also play a role in systemic colonization. It may be necessary for $X$. fastidiosa to first digest the pectin component of the pit membrane in order to expose the cell-wall polysaccharides that are then targeted by glucanases and xylanases. In support of this hypothesis, in vitro studies of the plant cell-wall breakdown show that the digestion of the hemicellulosic polysaccharides (e.g., glucans) is facilitated by first digesting the pectin portion of the cell wall (Keegstra et al. 1973). A less-likely explanation for this delayed movement might be physical damage to the xylem pit membranes.

Analysis of $X$. fastidiosa populations measured in petioles showed that populations were significantly higher for the wild type than the mutant. Likewise, $R$. solanacearum $\mathrm{pglA}^{-}$mutant populations were also found to be lower than wild type in tomato plants (Huang and Allen 2000). X. fastidiosa must digest pectin in pit membranes in order to move from vessel to vessel, but this digested pectin is also likely used as a nutrient source that would augment the otherwise dilute nutrient composition of the xylem sap. Because the X. fastidiosa pglA mutant cannot break down pectin polymers, it cannot utilize this component of the cell wall as a potential carbon source. This could explain, at least in part, why the $X$. fastidiosa $p g l A^{-}$ mutant populations were smaller than wild-type populations. No differences were observed between the growth curves of the wild-type $X$. fastidiosa and the $X$. fastidiosa pglA ${ }^{-}$mutant when they were grown in PD3 medium; therefore, this mutant does not appear to be compromised in its ability to metabolize nutrients that are present in its environment. Analysis of xylem sap from grapevines inoculated with wild-type $X$. fastidiosa revealed pectin breakdown products, which indicates that pectin-derived oligosaccharides are available for bacterial energy metabolism (Labavitch et al. 2001). In addition, the X. fastidiosa $\mathrm{pglA} \mathrm{A}^{-}$mutant is restricted to the xylem vessels in which it was introduced. Therefore, growth of the population would be limited because the mutant has less access to the xylem sap flow and the nutrients that the sap carries. Additional microscopy studies could provide insights into the colonization and distribution of the $p g l A^{-}$mutant versus wild-type $X$. fastidiosa in grapevine xylem elements over time.

Our attempts to detect direct activity of PG in infected grapevine xylem sap and leaf or petiole tissue using radial diffusion assays and spectrophotometric reducing sugar assays 
(Gross 1982; Taylor and Secor 1988) were unsuccessful. Levels of PG may be lower at the time of sample collection (presymptomatic and postsymptomatic) than our ability to detect activity. We also tried to induce the expression of PG in PD3 media amended with commercially available citrus pectin, grapevine cell walls, or the diffusible signal factor from $X$. campestris; these attempts were unsuccessful as well. PD3 is a nutrient-rich, complex medium, and it is possible that the PG expression is under catabolite repression by the large amounts of glucose found in the starch component of PD3 medium. However, the recombinant $X$. fastidiosa PglA protein, when expressed in $E$. coli, was capable of degrading pectin in vitro, indicating that this gene encodes a biochemically functional PG.

The results of the pathogenicity assay demonstrate that PG is clearly required for the development of PD in grapevines. Grapevines inoculated with the $X$. fastidiosa $p g l A^{-}$mutant developed none of the symptoms associated with PD. The movement assay showed that the mutant is not as efficient at systemically colonizing grapevines as wild-type $X$. fastidiosa. Although we did not quantify the specific distribution of the pglA $X$. fastidiosa mutant or wild-type X. fastidiosa cells in xylem elements in the inoculated vines, the isolation of lower populations of the mutant compared with wild-type $X$. fastidiosa suggests that the mutant likely colonized fewer xylem elements than the wild type. If fewer elements were colonized, then fewer vessels had the potential to become occluded with bacterial aggregates, which is correlated with the development of PD symptoms (Newman et al. 2003). Other reports indicated that avirulent strains of $X$. fastidiosa were unable to move beyond the point of inoculation in susceptible grapevine cultivars (Hopkins 1985; Fry and Milholland, et al. 1990a.). There is no information to suggest whether these avirulent strains are PG-deficient. The results of this study are consistent with the hypothesis by Hopkins (1989) that X. fastidiosa pathogenicity is dependent on systemic movement and successful colonization in the plant.

Several studies have investigated the possible role of various $X$. fastidiosa genes in virulence. Guilhabert and associates (2005) reported that two hemagglutinin-minus mutants were hypervirulent in grapevines, indicating that hemagglutinins are important in attenuating $X$. fastidiosa virulence. Additionally, a mutant deficient in the production of a diffusible signal molecule predicted to be involved in cell-to-cell signaling is hypervirulent in grapevines, thus indicating that $X$. fastidiosa may regulate some of its virulence factors via the rpf operon (Newman et al. 2004). X. fastidiosa mutants in two of the type IV pili genes are deficient in basipetal movement, but effects on pathogenicity were not reported (Meng et al. 2005). Fimbriae do not appear to be involved in pathogencity, because mutations in several $X$. fastidiosa fimbriae genes had no effect on pathogenicity (Feil et al. 2003). X. fastidiosa possesses two type I secretion systems (Van Sluys et al. 2003). Marker exchange mutagenesis of an X. fastidiosa TolC homolog, a structural protein of the type I secretion system, produced mutants that were nonpathogenic in grapevine due to their inability to survive in planta (Reddy and Gabriel, 2005).

We currently do not have the means to complement $X$. fastidiosa in planta to test if the wild-type pglA gene can restore virulence and movement to the pglA ${ }^{-}$X. fastidiosa mutant. Therefore, complementation tests were not performed. Aguero and associates (2005) transformed Vitis vinifera $\mathrm{cv}$. Thompson seedless and cv. Chardonnay with the gene encoding the pear fruit PG-inhibiting protein (PGIP) under the control of the constitutively expressed Cauliflower mosaic virus $35 \mathrm{~S}$ promoter. The PGIP-expressing vines accumulated PGIP in the xylem sap and developed PD symptoms at a slower rate and to a lesser extent than control vines, which provides additional evidence that PG is an important effector in $X$. fastidiosa virulence. Now that a biochemically active $X$. fastidiosa PG has been expressed in E. coli, it should be possible to search for additional plant PGIPs that have higher anti-PG activity than the pear PGIP. If discovered and expressed in transgenic grapevines, the high-activity PGIP may provide even greater attenuation of PD symptoms.

\section{MATERIALS AND METHODS}

Bacterial strains, plasmids, and PCR primers.

All bacterial strains, plasmids, and primers used in this study are listed in Table 4.

\section{Media and growth of bacterial strains.}

$X$. fastidiosa was grown at $28^{\circ} \mathrm{C}$ in PD3 broth and solid medium (Davis et al. 1981). E. coli strains were cultured at $37^{\circ} \mathrm{C}$ in Luria-Bertani medium (LB). When needed, antibiotics were added to media at the following concentrations: kanamycin, 5 $\mu \mathrm{g} / \mathrm{ml}$ (selection for insertion into $X$. fastidiosa); kanamycin, $30 \mu \mathrm{g} / \mathrm{ml}$ (selection of transformed E. coli); and ampicillin, $100 \mu \mathrm{g} / \mathrm{ml}$.

\section{DNA manipulations.}

Chromosomal DNA of $X$. fastidiosa was isolated using the DNeasy tissue kit as specified by the manufacturer (Qiagen, Chatsworth, CA, U.S.A.). X. fastidiosa was transformed by electroporation as previously described (Guilhabert et al. 2001). Isolation of plasmid DNA was performed using the Qiagen miniprep kit. Restriction digests, cloning, subcloning, and transformation of E. coli strains were performed by standard procedures (Sambrook and Russell 2001).

\section{PCR amplification, cloning, and disruption of the pglA ORF.}

PCR was used to amplify the pglA (PD1485) ORF from $X$. fastidiosa genomic DNA. For all PCR reactions the following parameters were used: denaturation at $95^{\circ} \mathrm{C}$ for $1 \mathrm{~min}(5 \mathrm{~min}$ for first cycle), annealing for $1 \mathrm{~min}$ at $55^{\circ} \mathrm{C}$ for primers pgfwd and pgrev and $60^{\circ} \mathrm{C}$ for primers kan-2-fp- 1 and pgchkrev and pgchkfwd and kan-2-rp-1 (Fig. 1). The extension step was $72^{\circ} \mathrm{C}$ for $2 \mathrm{~min}(10$-min final cycle). All PCR reactions were carried out for 35 cycles. A 1,695-bp PCR product containing the entire $p g l A$ ORF was amplified from Fetzer strain $X$. fastidiosa genomic DNA using primers pgfwd and pgrev. The PCR product was cloned into pCR2.1-TOPO to generate pMCR1 (Invitrogen, Carlsbad, CA, U.S.A.). pMCR1 was linearized utilizing the unique NheI restriction site located at position $927 \mathrm{bp}$ of the cloned pglA fragment. The annealed NheI adaptor was then cloned into pMCR1 to generate pMCR2. pMCR2 was digested with $\mathrm{SacI}$ and $\mathrm{XbaI}$ to generate a 1,794 bp fragment that was cloned into pUC18 (Invitrogen), which does not replicate in $X$. fastidiosa, to generate pMCR3. The cloned $X$. fastidiosa pglA ORF contains a unique $M f e I$ site that generated a cohesive end that is compatible with EcoRI. The Tn903<kan-2> cassette and the associated promoter that is expressed in $X$. fastidiosa are contained in a 1,238-bp EcoRI fragment (Guilhabert et al. 2001). The EcoRI Tn903 cassette was cloned into $M f e I$-digested pMCR3 to create pMCR4. Disruption of the pglA ORF was confirmed by sequencing pMCR4.

\section{Electroporation.}

Electrocompetent $X$. fastidiosa Fetzer cells were prepared as previously described (Guilhabert et al. 2001). Marker exchange mutagenesis was accomplished by electroporating $2 \mu \mathrm{g}$ of pMCR4 DNA into electrocompetent $X$. fastidiosa cells as previously described (Guilhabert et al. 2001). Following electro- 
poration, transformants were selected on PD3 media containing $5 \mu \mathrm{g}$ of kanamycin per milliliter.

\section{Confirmation of $\mathrm{pglA}$ gene replacement.}

PCR using the pgfwd and pgrev primers confirmed that a double crossing-over event had occurred in some of the $\mathrm{Kan}^{+}$ transformants. In order to confirm that the Tn903<kan-2>/pglA ORF construct had replaced the wild-type gene, we used PCR primers specific to the DNA flanking the pglA gene (pgchkfwd and pgchkrev) in combination with primers specific to the Tn903<kan-2> cassette (kan-2-fp-1 and kan2-rp-1). Sequencing of these PCR fragments confirmed that the Tn903<kan$2>/ p g l A$ ORF integrated and replaced the wild-type $p g l A$ ORF.

\section{Pathogenicity and movement assays.}

In the pathogenicity assay, Vitis vinifera cv. Chardonnay grapevines that were grown in the greenhouse for 4 months were pin-prick inoculated using a 20-gauge syringe needle (Hill and Purcell 1995). Each of 10 plants per treatment was inoculated twice on the stem and four internodes up from the base of the plant with $20 \mu \mathrm{l}$ drops of a $10^{8} \mathrm{CFU} / \mathrm{ml}$ solution of wild-type $X$. fastidiosa, pglA $X$. fastidiosa or $\mathrm{H}_{2} 0$. Twelve weeks after inoculation, and weekly thereafter for nine more weeks, plants were rated for PD symptoms on a scale from 0 to 5 (Guilhabert and Kirkpatrick 2005; Hopkins 1985), in which $0=$ no PD symptoms, $1=$ one or two leaves just beginning to show marginal necrosis, $2=$ two to three leaves with significant marginal necrosis, $3=$ one half or more of the leaves showing marginal necrosis and a few match sticks (attached petioles whose leaf blade had abscised), $4=$ all of the leaves showing heavy scorching and numerous matchsticks, and $5=$ a dead vine.
Plants were inoculated in the same manner for the movement assays but using 20 plants per treatment. Populations of $X$. fastidiosa wild type and $p g l A^{-} X$. fastidiosa mutant were quantified from petioles sampled at the point of inoculation, 25 , and $37 \mathrm{~cm}$ above the point of inoculation at 13,14 , and 15 weeks postinoculation, respectively. In addition, we isolated the $p g l A^{-} X$. fastidiosa mutants from petioles $25 \mathrm{~cm}$ above the point of inoculation 20 weeks postinoculation. We were unable to harvest petioles from the wild-type inoculated plants at the 20 -week timepoint due to severe defoliation and vine death. Petioles were weighed, surface-sterilized with 95\% EtOH (30 s) and $1.2 \%$ sodium hypochlorite $(30 \mathrm{~s})$, and then, rinsed two times in sterile distilled $\mathrm{H}_{2} \mathrm{O}(30 \mathrm{~s})$ and placed in mesh sample bags (Agdia, Inc., Elkhart, IN, U.S.A.) containing $2 \mathrm{ml}$ of sterile $1 \times$ potassium phosphate buffered saline. Samples were macerated with a grinding machine (Bioreba AG, Reinach, Switzerland). Serial dilutions of the macerate were plated on PD3 or PD3 medium containing $5 \mu \mathrm{g}$ of kanamycin per milliliter, incubated at $28^{\circ} \mathrm{C}$, and resulting colonies were counted after 10 days. The pathogenicity and movement assays were replicated twice using two different $p g l A^{-} X$. fastidiosa clones. The data presented in Table 2 represents the mean values of two separate experiments using two different $p g l A^{-} X$. fastidiosa clones.

\section{Statistical analysis.}

We used a $2 \times 2$ contingency table analysis at a $99 \%$ confidence level to assess if the mutant was hindered in its ability to move in planta as compared with the wild type. Potential differences in the sizes of the bacterial populations of the $X$. fastidiosa mutant and the wild type at different distances from the point of inoculation were determined using a repeated-meas-

Table 4. Plasmids, strains, and primer sequences used in this study

\begin{tabular}{|c|c|c|}
\hline Plasmids, primers, strains & Relevant characteristics or primer sequence $^{\mathrm{a}}$ & Source \\
\hline \multicolumn{3}{|l|}{ Plasmids } \\
\hline pUC18 & pMB1 derivative, rep (pMB1), bla $\left(\mathrm{Ap}^{\mathrm{r}}\right)$, lacZ & Roche \\
\hline pCR2.1-TOPO vector & pUC18 derivative, $\operatorname{kan}^{\mathrm{r}}$, bla $\left(\mathrm{Ap}^{\mathrm{r}}\right)$, lacZ & Invitrogen \\
\hline pMCR1 & pCR2.1-TOPO vector with 1,695 -bp $\mathrm{pglA}$ fragment & This study \\
\hline pMCR2 & pMCR1 with NheI adaptor insertion & This study \\
\hline pMCR3 & pUC18 with $p g l A:: N h e \mathrm{I}$ adaptor & This study \\
\hline pMCR4 & pMCR3 with $p g l A:: \operatorname{Tn} 903<$ kan-2> & This study \\
\hline pET29 b(+) & $\mathrm{Km}^{\mathrm{r}}$ & Novagen \\
\hline pMCR5 & pET-29b(+) with $p g l A$ insertion & This study \\
\hline \multicolumn{3}{|l|}{ Primers } \\
\hline pgfwd & GTGCCATGGCTTCCTTAC $^{\mathrm{b}}$ & This study \\
\hline pgrev & TACAGCTTCGAATGGACACA ${ }^{c}$ & This study \\
\hline NheI adaptor & CTAGCCAATTGG $^{\mathrm{d}}$ & This study \\
\hline kan-2fp-1 & ACСТACAACAAAGCTCTCATCAACC & Invitrogen \\
\hline pgchkrev & CACAGGATCTGGTCGTGTCT & This study \\
\hline kan2-rp-1 & GCAATGTAACATCAGAGATTTTGAG & Invitrogen \\
\hline pgchkfwd & TTCGTGCACACCTTCGACC & This study \\
\hline pgoxinfwd & GAAATCTGGGGTGACGTTGT & This study \\
\hline pgoxinrev & CAGACGACGCATGCATATT & This study \\
\hline pgoxfwd2 & TTTCCCATGGACCTTGACCGTTT ${ }^{\mathrm{b}}$ & This study \\
\hline pgoxrev5 & TTGGACACACGGCCGTTAGATAGGCGAATCA & This study \\
\hline T7 promoter & TAATACGACTCACTATAGGG & Novagen \\
\hline $\mathrm{T} 7$ terminator & GCTAGTTATTGCTCAGCGG & Novagen \\
\hline \multicolumn{3}{|l|}{ Strains } \\
\hline \multicolumn{3}{|l|}{ Escherichia coli } \\
\hline TOP10 & $\begin{array}{l}\mathrm{F}^{-} \text {mcrA } \Delta(m r r-h s d \mathrm{RMS}-m c r \mathrm{BC}) \varphi 80 l a c \mathrm{Z} \Delta \mathrm{M} 15 \Delta l a c \mathrm{X} 74 \text { rec } \mathrm{A} 1 \\
\text { araD139 } \Delta(\text { araleu }) 7697 \mathrm{gal} U \text { gal } K \operatorname{rps} L(\text { StrR }) \text { end } A 1 \text { nup } G\end{array}$ & Invitrogen \\
\hline BL21 (DE3) & $\mathrm{F}^{-}$ompT hsd $\mathrm{S}_{\mathrm{B}}\left(\mathrm{r}_{\mathrm{B}}^{-} \mathrm{m}_{\mathrm{B}}^{-}\right)$gal dcm (DE3) & Novagen \\
\hline \multicolumn{3}{|l|}{ Xylella fastidiosa } \\
\hline Fetzer & $\ldots$ & Napa, CA \\
\hline
\end{tabular}

\footnotetext{
${ }^{a}$ Primer sequences are presented $5^{\prime}$ to $3^{\prime} ; \mathrm{Ap}^{\mathrm{r}}$ and $\mathrm{Kan}^{\mathrm{r}}$ indicated ampicillin and kanamycin resistant, respectively.

${ }^{\mathrm{b}}$ The restriction $N c o$ I site is shown in bold.

${ }^{\mathrm{c}}$ The restriction site $B s t \mathrm{BI}$ is shown in bold.

d The restriction site, $M f e I$, is shown in bold.

e The restriction site, EagI is shown in bold.
} 
ures ANOVA test. The pathogenicity assay data were analyzed using a $5 \times 2$ contingency table analysis at a $99 \%$ confidence level.

\section{Cloning the pglA ORF into an expression vector.}

The pglA ORF was PCR-amplified with the Expand high fidelity Taq polymerase (Roche Applied Science, Indianapolis, IN, U.S.A.) from genomic $X$. fastidiosa DNA. Primers pgoxfwd 2 and pgoxrev5 were designed to amplify a product that began at the ATG start codon and ended immediately after the TAA stop codon to prevent the addition of the vectorencoded carboxy terminal 6 histidine tag. The primers also contained the restriction sites NcoI and EagI (Table 4). The following PCR parameters were used: denaturation at $94^{\circ} \mathrm{C}$ for $1 \mathrm{~min}(2 \mathrm{~min}$ for the first cycle $)$, annealing at $1 \mathrm{~min}$ at $55^{\circ} \mathrm{C}$, and extension for $2 \mathrm{~min}$ at $72^{\circ} \mathrm{C}$. (6-min final cycle). The PCR reaction was carried out for 35 cycles. The NcoI-EagI fragment obtained after digestion was then cloned into the pET$29 b(+)$ expression vector to create the plasmid pMCR5. Sequencing with pgoxfwd 2 and pgrev 5 as well as a set of internal primers (pginfwd and pginrev) confirmed that the insertion was cloned in-frame with no introduced mutations.

\section{Expression of a pglA fusion protein in Esherichia coli.}

The pMCR5 construct was transformed into chemically competent $E$. coli Novablue (Novagen, EMD Biosciences, La Jolla, CA, U.S.A.) by heat shock and was plated on LB medium containing $30 \mu \mathrm{g}$ of kanamycin per milliliter. Plasmids were extracted from transformants and were screened by restriction analysis for the correct insertion of the pglA amplicon. A plasmid with the correct size insertion was sequenced using the $\mathrm{T} 7$ promoter and $\mathrm{T} 7$ terminator and pginchkfwd and pginchkrev primers to confirm that no mutations were introduced during PCR amplification. A plasmid with the correct insertion was used to transform chemically competent $E$. coli BL21(DE3) (Novagen, EMD Biosciences). A fresh transformant was used for protein expression. Single colonies were grown to an optical density at $600 \mathrm{~nm}\left(\mathrm{OD}_{600}\right)=0.5$ at $37^{\circ} \mathrm{C}$ in $2 \mathrm{ml}$ of LB broth containing $30 \mu \mathrm{g}$ of kanamycin per milliliter. The cells were harvested by centrifugation and were resuspended in $150 \mathrm{ml}$ of $\mathrm{LB}$ broth containing kanamycin at 30 $\mu \mathrm{g} / \mathrm{ml}$. The cells were grown at $37^{\circ} \mathrm{C}$ with vigorous shaking to $\mathrm{OD}_{600}=0.5$, and then, were induced with IPTG to a final concentration of $0.6 \mathrm{mM}$. Cultures were then incubated at $4^{\circ} \mathrm{C}$ overnight with vigorous shaking. Aliquots were removed before and after induction and were analyzed by SDS-PAGE electrophoresis to confirm the presence of the recombinant protein. BL21 (DE3) transformed with pET-29b (+) containing no insert was used as a negative control.

\section{Enzymatic activity \\ of the recombinant $X$. fastidiosa PglA protein.}

PG activity (hydrolysis of PGA) was confirmed by reducing sugar assays using PGA as substrate and examination of digestion products using HPLC. Following expression, E. coli cells transformed with either pMCR5 or the empty pET29-b (+) vector were harvested by centrifugation for $15 \mathrm{~min}$ at 8,000 $\mathrm{rpm}$. The cell pellet was resuspended in $0.5 \mathrm{M} \mathrm{NaCl}, 50 \mathrm{mM}$ HEPES, $\mathrm{pH} 7.5$, containing $0.35 \mathrm{mg}$ of lysozyme per milliliter and Complete protease inhibitor cocktail, pH 7.5 (Roche Diagnostics, Manheim, Germany) and was incubated at room temperature for $30 \mathrm{~min}$. The lysate was sonicated on ice in five, 10 -s bursts, followed by gentle stirring at room temperature for $30 \mathrm{~min}$, followed by dialysis at $4^{\circ} \mathrm{C}$ against two changes of distilled water using $1,000 \mathrm{kDa}$ molecular mass cut-off dialysis tubing. A 1-ml sample of the resulting protein extract from either cells transformed with pMCR5 or the empty pET29- $\mathrm{b}(+)$ vector was incubated with $1 \mathrm{ml}$ of $0.2 \%$ PGA (MP Biomedicals, Solon, OH, U.S.A.) in $0.1 \mathrm{M}$ sodium acetate, $\mathrm{pH}$ 5.0. Protein extract incubated without PGA and PGA incubated without protein extract served as enzyme and substrate blanks, respectively. Reactions were performed in screw-cap tubes, and a drop of toluene was added to all the reaction mixtures to prevent microbial growth. Reaction mixtures were incubated at $37^{\circ} \mathrm{C}$ while shaking at $125 \mathrm{rpm}$. Aliquots $(200 \mu \mathrm{l})$ were taken immediately (time 0 ) and at 24-h intervals during incubation. Each aliquot was assayed for reducing groups using 2cyanoacetamide, as described by Gross (1982). Assays were performed in triplicate and were repeated three times. HPLC analysis was performed using a Dionex BioLC HPLC module equipped with a pulsed amperiometric detector. The acidic oligomers were separated on a Dionex CarboPac PA-1 $(4 \times 250$ $\mathrm{mm}$ ) anion exchange column using a sodium acetate gradient, as described by Melotto and associates (1994). Additionally, the peak eluting at $23.20 \mathrm{~min}$ was collected and assayed for uronic acid content, using the method described by Blumenkrantz and Asboe-Hansen (1973).

\section{LITERATURE CITED}

Aguero, C. B., Uratsu, S. L., Greve, L. C., Powell, A. L. T., Labavitch, J. M., Meredith, C. P., and Dandekar, A. M. 2005. Evaluation of tolerance to Pierce's Disease and Botrytis in transgenic plants of Vitis vinifera L. expressing the pear PGIP gene. Mol. Plant Pathol. 6:43-51.

Alghisi, P., and Favoron, F. 1995. Pectin-degrading enzymes and plantparasite interactions. Eur. J. Plant Pathol. 101:365-375.

Baron-Epel, O., Gharyal, P. K., and Schindler, M. 1988. Pectins as mediators of wall porosity in soybean. Planta 175:389-395.

Blumenkrantz, N., and Asboe-Hansen, G. 1973. New method for quantitative determination of uronic acids. Anal. Biochem. 53:484-489.

Carpita, N, C., and Gibeaut, D. M. 1993. Structural models of cell walls in flowering plants: Consistency of molecular structure with the physical properties of the walls during growth. Plant J. 3:1-10.

Choat, B., Ball, M., Luly, J., and Holtum, J. 2003. Pit membrane porosity and water stress-induced cavitation in four co-existing dry rainforest species. Plant Physiol. 131:41-48.

Collmer, A., and Keen, N. T. 1986. The role of pectic enzymes in plant pathogenesis. Annu. Rev. Phytopathol. 24:303-409.

Davis, M. J., Purcell, A. H., and Thomson, S. V. 1978. Pierce's disease of grapevines: Isolation of the causal bacterium. Science 199:75-77.

Davis, M. J., French, W. J., and Schaad, N. W. 1981. Axenic culture of the bacteria associated with phony disease of peach and plum leaf scald Curr. Microbiol. 6:309-314.

Dow, J. M., Milligan, D. E., Jamieson, L., Barber, C., and Daniels, J. D. 1989. Molecular cloning of a polygalacturonase gene from Xanthomonas campestris pv. campestris and role of the gene product in pathogenicity. Physiol. Mol. Plant Pathol. 35:113-120.

Dow, J. M. Scofield, G., Trafford, K., Turner, P. C., and Daniels, J. D. 1987. A gene cluster in Xanthomonas campestris pv. campestris required for pathogenicity controls the excretion of polygalacturonate lyase and other enzymes. Physiol. Mol. Plant Pathol. 31:261-271.

Esau, K. 1948. Anatomic effects of the viruses of Pierce's disease and phony peach. Hilgardia 18(12):423-482.

Feil, H., Feil, W. S., Detter, J. C. Purcell, A. H. and Lindow, S. E. 2003. Site-directed disruption of the fimA and fimF fimbrial genes of Xylella fastidiosa. Phytopathology 93:675-680.

Fry, S. M., and Milholland, R. D. 1990a. Response of resistant, tolerant, and susceptible grapevine tissues to invasion by the Pierce's disease bacterium, Xylella fastidiosa. Phytopathology 80:66-69.

Fry, S. M., and Milholland, R. D. 1990b. Multiplication and translocation of Xylella fastidiosa in petioles and stems of grapevines resistant, tolerant, and susceptible to Pierce's disease. Phytopathology 80:61-65.

Goodwin, P. H., DeVay, J. E., and Meredith, C. P. 1988a. Roles of water stress and phytotoxins in the development of Pierce's disease of the grapevine. Physiol. Mol. Plant Pathol. 32:1-15.

Goodwin, P. H., DeVay, J. E., and Meredith, C. P. 1988b. Physiological responses of Vitis vinifera cv. "Chardonnay" to infection by the Pierce's disease bacterium. Physiol. Mol. Plant Pathol. 32:17-32.

Gross, K. C. 1982. A rapid and sensitive spectrophotometric method for assaying polygalacturonase using 2-cyanoacetamide. Hortic. Sci. 17:933-984.

Guilhabert, M. R., and. Kirkpatrick, B. C. 2005. Identification of Xylella 
fastidiosa antivirulence genes: Hemagglutinin adhesins contribute to biofilm maturation to $X$. fastidiosa and colonization and attenuate virulence. Mol. Plant-Microbe Interact. 18: 856-868.

Guilhabert, M. R., Hoffman, L. M., Mills, D. A., and Kirkpatrick, B. C. 2001. Transposon mutagenesis of Xylella fastidiosa by electroporation of Tn5 synaptic complexes. Mol. Plant-Microbe Interact. 14:701-706.

Hill, B. L., and Purcell, A. H, 1995. Multiplication and movement of Xylella fastidiosa within grapevine and four other plants. Phytopathology 85:1368-1372.

Hopkins, D. L. 1985. Physiological and pathological characteristics of virulent and avirulent strains of the bacterium that causes Pierce's disease of grapevine. Phytopathology 75:713-717.

Hopkins, D. L. 1989. Xylella fastidiosa: Xylem-limited bacterial pathogen of plants. Annu. Rev. Phytopathol. 27:271-290.

Huang, Q., and Allen, C. 2000. Polygalacturonases are required for rapid colonization and full virulence of Ralstonia solanacearum in tomato plants. Physiol. Mol. Plant Pathol. 57:77-83.

Keegstra, K., Talmadge, K. W., Bauer, W. D., and Albersheim, P. 1973. The structure of plant cell walls. III. A model of the walls of suspension-cultured sycamore cells based on the interconnections of the macromolecular components. Plant Physiol. 51:188-196.

Koutajansky, A. 1987. Molecular genetics of pathogenesis by soft-rot bacteria. Annu. Rev. Phytopathol. 25:405-430.

Labavitch, J. M., Matthews, M. A., and Rost, T. 2001. The development of Pierce's disease in xylem: The role of vessel cavitation, cell wall metabolism, and vessel occlusion. Pages 58-61 in: Pierce's Disease Research Symposium Proceedings, California Department of Food and Agriculture, San Diego, CA, U.S.A.

Labavitch, J. M., Matthews, M. A., and Greve, L. C. 2002. The development of Pierce's disease in xylem: The role of vessel cavitation, cell wall metabolism, and vessel occlusion. Pages 61-63 in: Pierce's Disease Research Symposium Proceedings, California Department of Food and Agriculture, San Diego, CA, U.S.A.

Labavitch, J. M., Matthews, M. A., and Greve, L. C. 2004. Linking the model of the development of Pierce's disease in grapevines to an understanding of the dynamics of glassy-winged sharpshooter transmission of Xylella fastidiosa to grapevines and grapevine gene expression markers of Pierce's disease. Pages 15-18 in: Pierce's Disease Research Symposium Proceedings, California Department of Food and Agriculture. San Diego, CA, U.S.A.

Lei, S.-P., Lin, H.-C., Heffernan, L., and Wilcox, G. 1985. Evidence that polygalacturonase is a virulence determinant in Erwinia carotovora. J. Bacteriol. 164 (2):831-835.

Melotto, E. Greve, L. C., and Labavitch, J. M. 1994. Cell wall metabolism in ripening fruit. VII. Biologically active pectin oligomers in ripening tomato (Lycopersicon esculentum Mill.) fruits. Plant Physiol. 106:575581

Meng, Y., Li,, Y., Galvani, C.D., Hao, G., Turner, J. N., Burr, T. J., and Hoch, H. C. 2005. Upstream migration of Xylella fastidiosa via pilusdriven twitching motility. J. Bacteriol 187 (16), 5560-5567.

Newman, K.L., Almeida, T.P.P., Purcell, A.H., and Lindow, S.E. 2003. Use of a green fluorescent strain for analysis of Xylella fastidiosa colonization of Vitis vinifera. Appl. Environ. Microbiol. 69:7319-7327.

Newman, K. L., Almeida R. P. P, Purcell, A. H. and Lindow, S. E. 2004. Cell-cell signaling controls Xylella fastidiosa interactions with both insects and plants. PNAS, 101:1737-1742.

Prade, R. A., Zhan, D., Ayoubi, P., and Mort, A. J. 1999. Pectins, pecti- nases and plant-microbe interactions. Biotechnol. Genet. Eng. Rev. 16:361-391.

Purcell, A. H., and Saunders, S. R. 1999. Fate of Pierce's disease strains on Xylella fastidiosa in common riparian plants in California. Plant Dis. 83:825-830.

Reddy, J. D., and Gabriel, D. W. 2005. Role of type I secretion in Pierce's disease. Pages 158-161 in: Pierce's Disease Research Symposium Proceedings. California Department of Food and Agriculture. San Diego, CA, U.S.A.

Rodriguez-Palenzuela, P., Burr, T. J., and Collmer, A. 1991. Polygalacturonase is a virulence factor in Agrobacterium tumefaciens biovar 3. J. Bacteriol. 173:6547-6552.

Salanoubat, M., Genin, S., Artiguenave, F., Gouzy, J., Mangenot, S., Arlat, M., Billault, A., Brottier, P., Camus, J. C., Cattolico, L., Chandler, M., Choisne, N., Claudel-Renard, C., Cunnac, S., Demange, N., Gaspin, C., Lavie, M., Moisan, A., Robert, C., Saurin, W., Schiex, T., Siguier, P. Thébault, P., Whalen, M., Wincker, P., Levy, M., Weissenbach, J., Boucher, C. A. 2002. Genome sequence of the plant pathogen Ralstonia solanacearum. Nature 415:497-502.

Sambrook, J., and Russell, D. W., 2001. Molecular Cloning: A Laboratory Manual, Vol. 3. Cold Spring Harbor Laboratory Press, Cold Spring Harbor, NY, U.S.A.

Schell, M. A., Roberts, D. P., and Denny, T. P. 1988. Analysis of the Pseudomonas solanacearum polygalacturonase encoded by $p g l A$ and its involvement in phytopathogenicity. J. Bacteriol. 170:4501-4508.

Simpson, A. J., Reinach, F. C., Arruda, P., Abreu, F. A., Acencio, M., Alvarenga, R., Alves, L. M., Araya, J. E., Baia, G. S., Baptista, C. S., Barros, M. H., Bonaccorsi, E. D., Bordin. S., Bové, J. M., Briones, M. R., Bueno, M. R., Camargo, A. A., Camargo, L. E., Carraro, D. M., Carrer, H., Colauto, N. B., Colombo, C., Costa, F. F., Costa, M. C., Costa-Neto, C. M., et al. 2000. The genome sequence of the plant pathogen, Xylella fastidiosa. Nature 406:151-157.

Spiro, M. D., Kates, K. A., Koller, A. L., O’Neill, M. A., Albersheim, P., and Darvill, A. G. 1993. Purification and characterization of biologically active1,4-linked $\alpha$-D-oligo-galacturonides after partial digestion of polygalacturonic acid with endopolygalacturonase. Carbohydr. Res. 247:9-20.

Taylor, R. J., and Secor, G. A. 1988. An improved diffusion assay for quantifying the polygalacturonase content of Erwinia culture filtrates. Phytopathology 78:1101-1103.

Thorne, E. T., Young, B. M., Young, G. M., Stevenson, J. F., Labavitch, J. M., Matthews, M. A., and Rost, T. L. 2006. The structure of xylem vessels in grapevine (Vitaceae) and a possible passive mechanism for the systemic spread of bacterial disease. Am. J. Bot. 93(4):497-504.

Van Sluys, M. A., de Oliveira, M. C., Monteiro-Vitorello, C. B., Miyaki. C. Y., Furlan, L. R., Camargo. L. E., da Silva, A. C., Moon, D. H., Takita, M. A., Lemos, E. G., Machado, M. A., Ferro, M. I., da Silva, F. R., Goldman, M. H., Goldman, G. H., Lemos, M. V., El-Dorry, H., Tsai, S. M., Carrer, H., Carraro, D. M., de Oliveira, R. C., Nunes, L. R., Siqueira, W. .J., Coutinho, L. L., Kimura, E. T., et al. 2003. Comparative analyses of the complete genome sequences of Pierce's disease and citrus-variegated chlorosis strains of Xylella fastidiosa. J. Bacteriol. 185 (3):1018-1026.

Zimmerman, M. H. 1983. Xylem Structure and the Ascent of Sap. Springer-Verlag, New York.

Zwieniecki, M. A., Melcher, P. J., and Holbrook, N. M. 2001. Hydrogel control of xylem hydraulic resistance. Science 291:1059-1062. 